\title{
Intrathoracic right subclavian artery cannulation in aortic arch surgery
}

Elizabeth L. Norton, MS, ${ }^{\mathrm{a}}$ Alex Makkinejad, BS, ${ }^{\mathrm{b}}$ Tan Le, BS, ${ }^{\mathrm{b}}$ Xiaoting Wu, PhD, ${ }^{\mathrm{b}}$ and Bo Yang, MD, $\mathrm{PhD}^{\mathrm{b}}$

From the ${ }^{\mathrm{a} C r e i g h t o n}$ University School of Medicine, Omaha, Neb and ${ }^{\mathrm{b}}$ Department of Cardiac Surgery, Michigan Medicine, Ann Arbor, Mich.

Dr Yang is supported by the National Heart, Lung, and Blood Institute (Grants K08 HL130614 and R01 HL141891), the Phil Jenkins Fund, and the Darlene and Stephen J. Szatmari Fund.

Disclosures: The authors reported no conflicts of interest.

The Journal policy requires editors and reviewers to disclose conflicts of interest and to decline handling or reviewing manuscripts for which they may have a conflict of interest. The editors and reviewers of this article have no conflicts of interest.

Date and number of Institutional Review Board approval: HUM00119716, approved September 26, 2016, and HUM00111673, approved on April 22, 2016.

Received for publication Feb 20, 2020; revisions received Feb 20, 2020; accepted for publication March 19, 2020; available ahead of print April 9, 2020.

Address for reprints: Bo Yang, MD, PhD, 1500 East Medical Center Drive, Ann Arbor, MI 48109 (E-mail: boya @ med.umich.edu).

JTCVS Techniques 2020;2:1-5

2666-2507

Copyright (c) 2020 The Authors. Published by Elsevier Inc. on behalf of The American Association for Thoracic Surgery. This is an open access article under the CC BY-NC-ND license (http://creativecommons.org/licenses/bync-nd/4.0/).

https://doi.org/10.1016/j.xjtc.2020.03.024

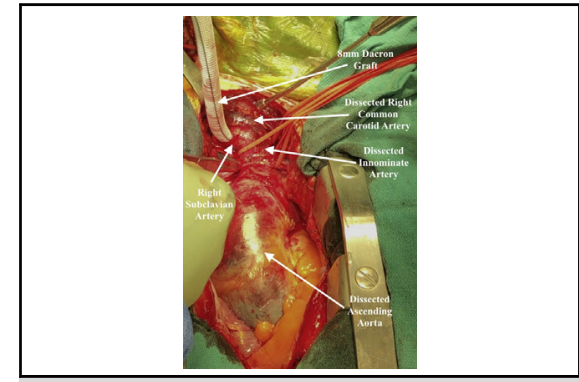

Acute type A aortic dissection repair with intrathoracic right subclavian artery cannulation.

\section{CENTRAL MESSAGE}

The intrathoracic right subclavian artery is a safe and effective site for cannulation for aortic arch surgery.

See Commentaries on pages 6 and 8.

Video clip is available online.

The arterial cannulation strategy for aortic arch surgery, especially in acute type A aortic dissection (ATAAD), remains variable. $^{1-3}$ Axillary artery cannulation protects the cerebral circulation from potential atherosclerotic debris but necessitates an additional incision or is sometimes too small. The innominate artery provides a larger artery for cardiopulmonary bypass and antegrade cerebral perfusion (ACP); however, it may be diseased or involved in the dissection. In our practice, we have shifted to intrathoracic cannulation of the right subclavian artery (RScA). This approach avoids an additional

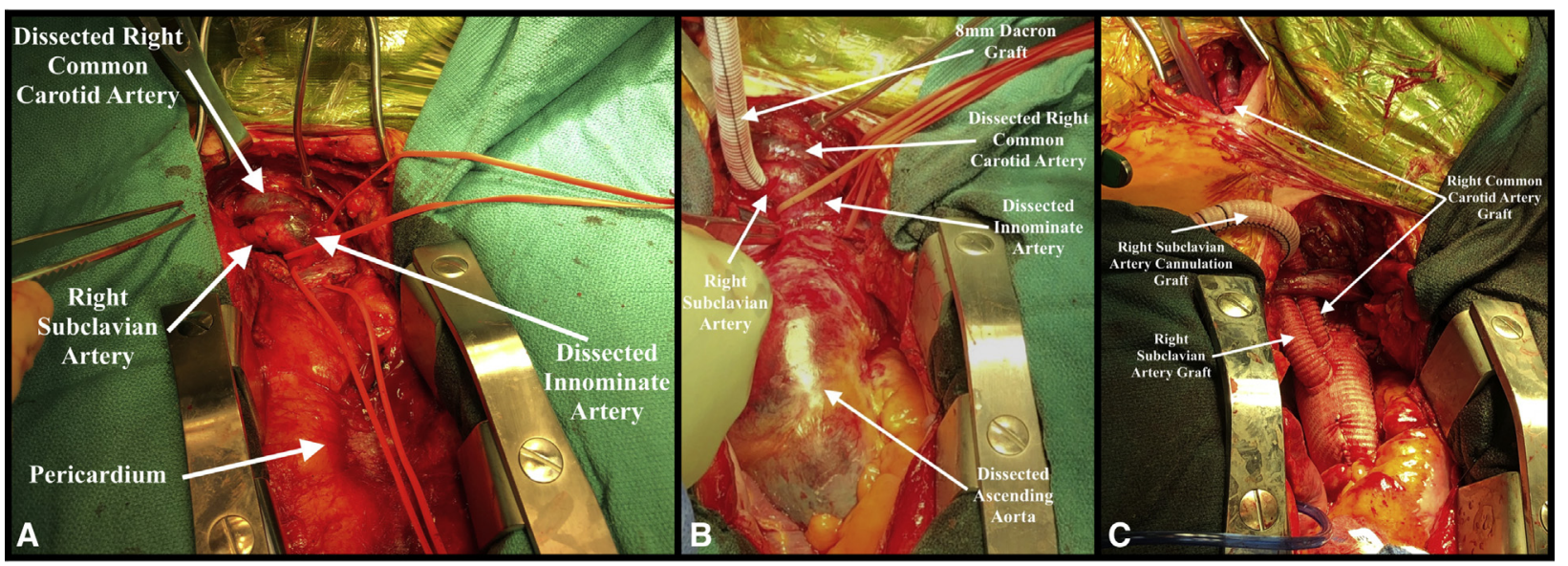

FIGURE 1. The right subclavian artery can be used as a cannulation site in aortic arch surgery. A, Intrathoracic isolation of the right subclavian artery for cannulation in a patient with an acute type A aortic dissection extending into the innominate and right common carotid arteries. B, Cannulation through an 8$\mathrm{mm}$ Dacron graft sewn to the right subclavian artery. C, Completion of an acute type A aortic dissection repair with an aortic root repair, zone 1 arch replacement, total right common carotid artery replacement and aorto-right subclavian artery bypass. 
TABLE 1. Demographics and preoperative outcomes

\begin{tabular}{|c|c|c|c|}
\hline Variable & Total $(\mathbf{N}=\mathbf{5 8})$ & ATAAD $(\mathbf{N}=\mathbf{3 4})$ & Other $(N=24)$ \\
\hline Patient age, y, median (IQR) & $63(49-71.5)$ & $63.5(48.5-75.5)$ & $60(49.5-70)$ \\
\hline Male sex, n (\%) & $31(53)$ & $22(65)$ & $9(37.5)$ \\
\hline Body surface area, $\mathrm{m}^{2}$, median (IQR) & $2.1(1.9-2.3)$ & $2.1(1.9-2.2)$ & $2.2(1.9-2.3)$ \\
\hline \multicolumn{4}{|l|}{ Preexisting comorbidities, n ( $\%)$} \\
\hline Hypertension & $47(81)$ & $25(74)$ & $22(92)$ \\
\hline Diabetes & $5(8.6)$ & $0(0)$ & $5(21)$ \\
\hline \multicolumn{4}{|l|}{ Smoking status, n (\%) } \\
\hline None & $14(24)$ & $9(26)$ & $5(21)$ \\
\hline Former & $26(45)$ & $11(32)$ & $15(62.5)$ \\
\hline Current & $18(31)$ & $14(41)$ & $4(17)$ \\
\hline Coronary artery disease, $\mathrm{n}(\%)$ & $18(31)$ & $4(12)$ & $14(58)$ \\
\hline Chronic obstructive pulmonary disease, $\mathrm{n}(\%)$ & $15(26)$ & $5(15)$ & $10(42)$ \\
\hline History of myocardial infarction, $\mathrm{n}(\%)$ & $5(8.6)$ & $1(2.9)$ & $4(17)$ \\
\hline History of stroke, $\mathrm{n}(\%)$ & $2(3.4)$ & $1(2.9)$ & $1(4.2)$ \\
\hline History of renal failure, $\mathrm{n}(\%)$ & $6(10)$ & $3(8.8)$ & $3(12.5)$ \\
\hline On dialysis, $\mathrm{n}(\%)$ & $1(1.7)$ & $1(2.9)$ & $0(0)$ \\
\hline Connective tissue disorder, $\mathrm{n}(\%)$ & $0(0)$ & $0(0)$ & $0(0)$ \\
\hline Bicuspid aortic valve, $\mathrm{n}(\%)$ & $10(17)$ & $1(2.9)$ & $9(37.5)$ \\
\hline Previous cardiac intervention, n (\%) & $18(31)$ & $6(18)$ & $12(50)$ \\
\hline Previous cardiac surgery, n (\%) & $8(14)$ & $1(2.9)$ & $7(29)$ \\
\hline \multicolumn{4}{|l|}{ Preoperative aortic insufficiency, $\mathrm{n}(\%)$} \\
\hline None & $16(28)$ & $9(26)$ & $7(29)$ \\
\hline Trace & $8(14)$ & $4(12)$ & $4(17)$ \\
\hline Mild & $10(17)$ & $8(24)$ & $2(8.3)$ \\
\hline Moderate & $15(26)$ & $10(29)$ & $5(21)$ \\
\hline Severe & $9(16)$ & $3(8.8)$ & $6(25)$ \\
\hline Ejection fraction, $\%$, median (IQR) & $55(55-60)$ & $55(55-60)$ & $58(54-61)$ \\
\hline \multicolumn{4}{|l|}{ NYHA function class, $\mathrm{n}(\%)$} \\
\hline III/IV & $10(17)$ & $5(15)$ & $5(21)$ \\
\hline Acute myocardial infarction & $1(1.7)$ & $1(2.9)$ & $0(0)$ \\
\hline Acute stroke & $3(5.2)$ & $3(8.8)$ & $0(0)$ \\
\hline Acute renal failure & $3(5.2)$ & $3(8.8)$ & $0(0)$ \\
\hline Acute paralysis & $0(0)$ & $0(0)$ & $0(0)$ \\
\hline Cardiogenic shock & $3(5.2)$ & $2(5.9)$ & $1(4.2)$ \\
\hline Preoperative creatinine, mg/dL, median (IQR) & $1.0(0.9-1.3)$ & $1.0(0.8-1.4)$ & $1.0(1.0-1.2)$ \\
\hline \multicolumn{4}{|l|}{ Medications, n (\%) } \\
\hline Anticoagulants & $4(6.9)$ & $1(2.9)$ & $3(12.5)$ \\
\hline Inotropes & $2(3.4)$ & $1(2.9)$ & $1(4.2)$ \\
\hline
\end{tabular}

$A T A A D$, Acute type A aortic dissection; IQR, interquartile range; NYHA, New York Heart Association.

incision as in the use of the right axillary artery, manipulation and clamping of the innominate artery, and graft material left on the innominate artery.

\section{METHODS}

This study was approved by the Institutional Review Board at the University of Michigan, Michigan Medicine, with a waiver of informed consent, and was in compliance with Health Insurance Portability and Accountability Act regulations.

\section{Study Population}

Between December 2014 and April 2018, 58 patients underwent aortic repair with moderate hypothermic circulatory arrest (HCA) and ACP via intrathoracic RScA cannulation by sewing an 8-mm Dacron graft to the artery. Indications included ATAAD ( $\mathrm{n}=34)$, aortic arch aneurysm $(\mathrm{n}=23)$, and infected ascending and arch graft $(\mathrm{n}=1)$.

The investigators leveraged Society of Thoracic Surgeons data elements from the University of Michigan's Cardiac Surgery Data Warehouse and electronic medical record review for data collection. 
TABLE 2. Intraoperative data

\begin{tabular}{|c|c|c|c|}
\hline Variables & Total $(\mathbf{N}=\mathbf{5 8})$ & $\operatorname{ATAAD}(\mathbf{N}=\mathbf{3 4})$ & Other $(N=24)$ \\
\hline \multicolumn{4}{|l|}{ Aortic root procedure, $\mathrm{n}(\%)$} \\
\hline None & $8(14)$ & $3(8.8)$ & $5(21)$ \\
\hline AVR only & $7(12)$ & $1(2.9)$ & $6(25)$ \\
\hline Bioprosthetic & $7(12)$ & $1(2.9)$ & $6(25)$ \\
\hline Mechanical & $0(0)$ & $0(0)$ & $0(0)$ \\
\hline Root replacement & $17(29)$ & $7(21)$ & $10(42)$ \\
\hline Bentall procedure & $13(22)$ & $4(12)$ & $9(37.5)$ \\
\hline Bioprosthetic & $9(16)$ & $3(8.8)$ & $6(25)$ \\
\hline Mechanical & $4(6.9)$ & $1(2.9)$ & $3(12.5)$ \\
\hline Inclusion root technique & $2(3.4)$ & $1(2.9)$ & $1(4.2)$ \\
\hline David VSARR & $2(3.4)$ & $2(5.9)$ & $0(0)$ \\
\hline Root repair, n (\%) & $26(45)$ & $23(68)$ & $3(12.5)$ \\
\hline Ascending replacement, $\mathrm{n}(\%)$ & $57(98)$ & $34(100)$ & $23(96)$ \\
\hline \multicolumn{4}{|l|}{ Aortic arch procedure, n (\%) } \\
\hline Hemiarch & $35(60)$ & $20(59)$ & $15(62.5)$ \\
\hline Zone 1 & $6(10)$ & $5(15)$ & $1(4.2)$ \\
\hline Zone 2 & $15(26)$ & $9(26)$ & $6(25)$ \\
\hline Zone 3 & $2(3.4)$ & $0(0)$ & $2(8.3)$ \\
\hline Frozen elephant trunk, n (\%) & $9(16)$ & $7(21)$ & $2(8.3)$ \\
\hline \multicolumn{4}{|l|}{ Concomitant procedures, $\mathrm{n}(\%)$} \\
\hline CABG & $7(12)$ & $2(5.9)$ & $5(21)$ \\
\hline Mitral valve & $3(5.2)$ & $1(2.9)$ & $2(8.3)$ \\
\hline Tricuspid valve & $4(6.9)$ & $0(0)$ & $4(17)$ \\
\hline CPB time, min, median (IQR) & $216(188-248)$ & $200(172.5-234.5)$ & $237.5(199.5-251)$ \\
\hline Cross-clamp time, min, median (IQR) & $146(109-185.5)$ & $123(96-161)$ & $168.5(152-190)$ \\
\hline HCA time, min, median (IQR) & $22(17-29)$ & $23(20-28)$ & $16.5(14-31)$ \\
\hline \multicolumn{4}{|l|}{ Antegrade cerebral perfusion, $\mathrm{n}(\%)$} \\
\hline Unilateral & $43(74)$ & $27(79)$ & $16(67)$ \\
\hline Bilateral & $15(26)$ & $7(21)$ & $8(33)$ \\
\hline Lowest temperature, ${ }^{\circ} \mathrm{C}$, median (IQR) & $24(21-26)$ & $24(22-26)$ & $23(21-28)$ \\
\hline \multicolumn{4}{|l|}{ Blood transfusion (PRBCs), n (\%) } \\
\hline 0 units & $36(62)$ & $18(53)$ & $18(75)$ \\
\hline 1 unit & $4(6.9)$ & $4(12)$ & $0(0)$ \\
\hline 2 units & $8(14)$ & $3(8.8)$ & $5(21)$ \\
\hline$\geq 3$ units & $10(17)$ & $9(26)$ & $1(4.2)$ \\
\hline
\end{tabular}

$A T A A D$, Acute type A aortic dissection; $A V R$, aortic valve replacement; $V S A R R$, valve-sparing aortic root replacement; $C A B G$, coronary artery bypass graft; $C P B$, cardiopulmonary bypass; $I Q R$, interquartile range; $H C A$, hypothermic circulatory arrest; $P R B C s$, packed red blood cells. Hemiarch: Aortic arch was resected from the base of the innominate artery to the base of the left subclavian artery, then the lesser curvature; no reimplantation of arch branches. Zone 1 arch: Aortic arch was divided between the innominate artery and left common carotid artery with reimplantation of the innominate artery or right common carotid artery and right subclavian artery separately. Zone 2 arch: Aortic arch was divided between the left common carotid artery and left subclavian artery with reimplantation of the innominate artery and left common carotid artery or right subclavian artery, right common carotid artery, and left common carotid artery separately. Zone 3 arch: Aortic arch was divided distal to the left subclavian artery with reimplantation of all arch branches.

\section{Surgical Techniques}

Following a standard median sternotomy, we dissected out the innominate artery, right common carotid artery, and RScA. The right recurrent laryngeal nerve, approximately $3 \mathrm{~cm}$ distal to the bifurcation, was wellvisualized and preserved. The RScA was examined and palpated to confirm the absence of dissection, atherosclerotic plaque, and calcification. The normal RScA appeared similar in the patients with and those without aortic dissection. The RScA was not used for cannulation if it was dissected, aneurysmal, or atherosclerotic or calcified. Vessel loops were sometimes placed around the RScA to retract the vessel. After heparinization, the RScA was clamped with a Satinsky clamp, and an arteriotomy was made. An 8-mm
Dacron graft was anastomosed to the RScA with 5-0 Prolene and connected to the arterial perfusion line with a $1 / 4 "-3 / 8$ " connector after deairing (Figure 1). The aortic root and arch repair were performed as described previously. $^{4-6}$

\section{Statistical Analysis}

Analyses provided descriptive information on the demographic, clinical, and surgical characteristics. Continuous variables were summarized as median (interquartile range), and categorical variables were reported as number $(\%)$ in frequency tables. 
TABLE 3. Causes and outcomes of all postoperative new-onset strokes

\begin{tabular}{|c|c|c|c|c|c|c|c|}
\hline Case & Timing & $\begin{array}{l}\text { Preoperative } \\
\text { conditions }\end{array}$ & Procedure & Clinical symptoms & Imaging findings & Potential causes & Outcomes \\
\hline 1 & $\begin{array}{c}\text { Immediate } \\
\text { stroke, } \\
\text { POD 1 }\end{array}$ & $\begin{array}{l}\text { Acute type A } \\
\text { dissection, } \\
\text { ruptured } \\
\text { ascending aorta }\end{array}$ & $\begin{array}{l}\text { Aortic root repair, } \\
\text { ascending aorta and } \\
\text { transverse arch } \\
\text { replacement } \\
\text { (unilateral ACP) }\end{array}$ & $\begin{array}{l}\text { Left facial weakness, } \\
\text { left-sided pronator } \\
\text { drift }\end{array}$ & $\begin{array}{l}\text { Right temporal, } \\
\text { frontal and parietal } \\
\text { lobes low } \\
\text { attenuation with } \\
\text { hemorrhagic } \\
\text { conversion }\end{array}$ & $\begin{array}{l}\text { Intraoperative PEA } \\
\text { arrest, hypotension }\end{array}$ & Resolved \\
\hline 2 & $\begin{array}{r}\text { Delayed } \\
\text { stroke, } \\
\text { POD } 7\end{array}$ & $\begin{array}{l}\text { Acute type A } \\
\text { dissection, } \\
\text { moderate AI, and } \\
\text { malignant } \\
\text { hypertension }\end{array}$ & $\begin{array}{l}\text { Aortic root repair, } \\
\text { ascending aorta, } \\
\text { and zone } 2 \\
\text { arch }+\mathrm{LCC}, \\
\text { innominate artery } \\
\text { replacement } \\
\text { (bilateral ACP due } \\
\text { to bovine trunk) }\end{array}$ & $\begin{array}{l}\text { Impaired language, } \\
\text { confusion }\end{array}$ & $\begin{array}{l}\text { Multifocal bilateral } \\
\text { watershed infarcts }\end{array}$ & $\begin{array}{l}\text { Relative hypotension } \\
\text { to previously } \\
\text { uncontrolled } \\
\text { hypertension }\end{array}$ & Resolved \\
\hline
\end{tabular}

$P O D$, Postoperative day; $A C P$, antegrade cerebral perfusion; $P E A$, pulseless electrical activity; $A I$, aortic insufficiency; $L C C$, left common carotid.

TABLE 4. Postoperative data

\begin{tabular}{|c|c|c|c|}
\hline Variable & Total $(\mathbf{N}=\mathbf{5 8})$ & $\operatorname{ATAAD}(\mathbf{N}=\mathbf{3 4})$ & Other $(N=\mathbf{2 4})$ \\
\hline Reoperation for bleeding, $\mathrm{n}(\%)$ & $0(0)$ & $0(0)$ & $0(0)$ \\
\hline Tamponade, n (\%) & $0(0)$ & $0(0)$ & $0(0)$ \\
\hline Deep sternal wound infection, $\mathrm{n}(\%)$ & $0(0)$ & $0(0)$ & $0(0)$ \\
\hline Postoperative myocardial infarction, n (\%) & $0(0)$ & $0(0)$ & $0(0)$ \\
\hline Sepsis, n (\%) & $0(0)$ & $0(0)$ & $0(0)$ \\
\hline Atrial fibrillation, n (\%) & $17(29)$ & $9(26)$ & $8(33)$ \\
\hline Cerebrovascular accident, $\mathrm{n}(\%)$ & $2(3.4)$ & $2(5.9)$ & $0(0)$ \\
\hline Transient ischemic attack, $\mathrm{n}(\%)$ & $0(0)$ & $0(0)$ & $0(0)$ \\
\hline Paraplegia, n (\%) & $0(0)$ & $0(0)$ & $0(0)$ \\
\hline New-onset acute renal failure, $\mathrm{n}(\%)$ & $3(5.2)$ & $3(8.8)$ & $0(0)$ \\
\hline Requiring dialysis, n (\%) & $2(3.4)$ & $2(5.9)$ & $0(0)$ \\
\hline Recurrent laryngeal nerve injury, n (\%) & $0(0)$ & $0(0)$ & $0(0)$ \\
\hline \multicolumn{4}{|l|}{ Vocal cord paralysis, $\mathrm{n}(\%)$} \\
\hline Left & $1(1.7)$ & $0(0)$ & $1(4.2)$ \\
\hline Right & $0(0)$ & $0(0)$ & $0(0)$ \\
\hline Pneumonia, n (\%) & $3(5.2)$ & $2(5.9)$ & $1(4.2)$ \\
\hline Prolonged ventilation, n (\%) & $19(33)$ & $15(44)$ & $4(17)$ \\
\hline Duration of intubation, h, median (IQR) & $22(17-39)$ & $25(18-66)$ & $21(16-30)$ \\
\hline Reintubation, n (\%) & $3(3.4)$ & $1(2.9)$ & $2(8.3)$ \\
\hline Postoperative length of stay, d, median (IQR) & $8(6-15)$ & $8.5(6-15)$ & $8(6-12)$ \\
\hline Total length of stay, d, median (IQR) & $9.5(6-17)$ & $9.5(6-16)$ & $10(6-19)$ \\
\hline Intraoperative mortality, $\mathrm{n}(\%)$ & $0(0)$ & $0(0)$ & $0(0)$ \\
\hline Mortality at discharge, $\mathrm{n}(\%)$ & $2(3.4)$ & $2(5.9)$ & $0(0)$ \\
\hline 30-d mortality, n (\%) & $3(5.2)$ & $3(8.8)$ & $0(0)$ \\
\hline
\end{tabular}

$A T A A D$, Acute type A aortic dissection; $I Q R$, interquartile range. 


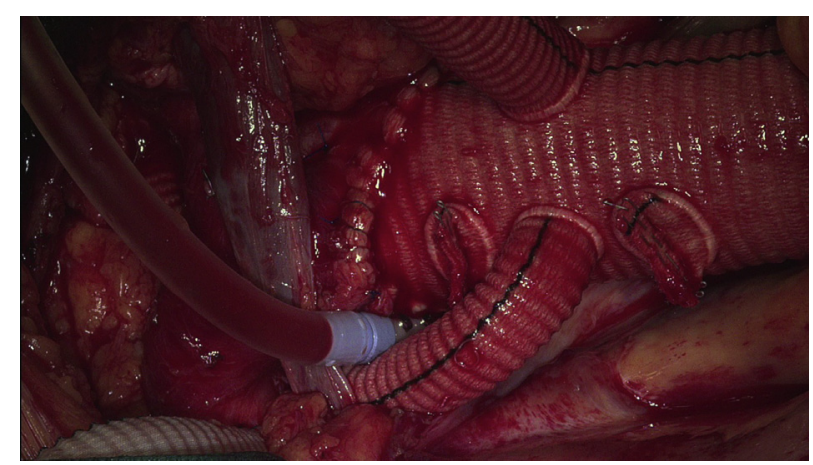

VIDEO 1. Discussion of the use of the intrathoracic right subclavian artery (RScA) in aortic arch surgery with detailed operative video of dissection and cannulation of the RScA in 3 different cases: (1) ascending and arch aneurysm repair, (2) acute type A aortic dissection repair, and (3) redo sternotomy with hypothermic circulatory arrest and antegrade cerebral perfusion for repair of a substernal ascending and arch aortic aneurysm. Video available at: https://www.jtcvs.org/article/S2666-2507(20) 30174-7/fulltext.

\section{RESULTS}

\section{Demographics and Intraoperative Data}

The median patient age was 63 years (Table 1). Thirtyfive patients $(60 \%)$ had a hemiarch replacement, and 23 $(40 \%)$ had a zone $1-3$ arch replacement with replacement of $1-4$ arch branches. The majority of patients $(74 \%)$ had unilateral ACP. The median hypothermic circulatory arrest time was 22 minutes, with an average lowest temperature of $24^{\circ} \mathrm{C}$. Fifty patients $(86 \%)$ underwent a concomitant aortic valve or root procedure (Table 2).

\section{Outcomes}

Among the 58 patients, the rates of postoperative newonset stroke and transient ischemic attack were 3\% (2 of 58) and $0 \%$, respectively. Both postoperative strokes occurred in patients with an ATAAD (Table 3). There were no right recurrent laryngeal nerve injuries. The inhospital mortality rate was 3\% ( 2 of 58) (Table 4$)$.

\section{DISCUSSION}

In this study, we report a low rate of neurologic complications, operative mortality, and no complications of the $\mathrm{RScA}$ or right upper extremity with intrathoracic RScA cannulation in aortic arch surgery with ACP. Use of the RScA via intrathoracic cannulation prevents the additional incision and the added risks (increased potential for blood loss outside the surgeon's direct vision and brachial plexus injury) as in axillary artery cannulation. It also avoids blocking the blood flow to the right common carotid artery, manipulation of the innominate artery, and the increased risk of neurologic complications from ischemia due to clamping and the potential for embolic stroke. It provides an alternative option if the innominate artery is involved in the dissection and perfuses the right vertebral artery for additional cerebral perfusion. In the long term, using the RScA eliminates the risk of thrombosis from the graft material sewn to the innominate artery causing postoperative and late stroke or transient ischemic attack. The dissection of the RScA should be very close the artery, to avoid injury to the right recurrent laryngeal nerve. Medial retraction of the innominate artery could facilitate the exposure of proximal RScA (Video 1). After dissection, the RScA is quite mobile with little tension a majority of the time. The right recurrent laryngeal nerve is easy to identify and preserve. There were no right recurrent laryngeal nerve injuries in our series.

In summary, intrathoracic RScA cannulation is a safe and effective method for elective and emergent aortic arch surgery with moderate HCA with ACP.

\section{References}

1. Lee TC, Kon Z, Cheema FH, Grau-Sepulveda MV, Englum B, Kim S, et al Contemporary management and outcomes of acute type A aortic dissection: an analysis of the STS adult cardiac surgery database. J Card Surg. 2018;33:7-18.

2. Parikh N, Trimarchi S, Gleason TG, Kamman AV, di Eusanio M, Myrmel T, et al. Changes in operative strategy for patients enrolled in the international registry of acute aortic dissection interventional cohort program. J Thorac Cardiovasc Surg. 2017; 153:S74-9.

3. Kreibich M, Chen Z, Rylski B, Bavaria JE, Brown CR, Branchetti E, et al Outcome after aortic, axillary, or femoral cannulation for acute type A aortic dissection. J Thorac Cardiovasc Surg. 2019;158:27-34.e9.

4. Yang B, Malik A, Waidley V, Kleeman KC, Wu X, Norton EL, et al. Short-term outcomes of a simple and effective approach to aortic root and arch repair in acute type A aortic dissection. J Thorac Cardiovasc Surg. 2018;155:1360-13670.e1.

5. Yang B, Norton EL, Hobbs R, Farhat L, Wu X, Hornsby WE, et al. Short- and long term outcomes of aortic root repair and replacement in patients undergoing acute type A aortic dissection repair: twenty-year experience. J Thorac Cardiovasc Surg. 2019;157:2125-36.

6. Yang B, Norton EL, Shih T, Farhat L, Wu X, Hornsby WE, et al. Late outcomes of strategic arch resection in acute type A aortic dissection. J Thorac Cardiovasc Surg. 2019;157:1313-21.e2. 